Wawasan

Jurnal Kediklatan Balai Diklat Keagamaan Jakarta PISSN 2548-9232; ISSN ...

Volume 1 Nomor 1 Tahun 2020

\title{
PENERAPAN MODEL EVALUASI KIRKPATRICK PADA PELATIHAN DASAR CPNS CALON HAKIM MA PADA MATA PELATIHAN ANEKA DI BALAI DIKLAT KEAGAMAAN JAKARTA
}

\author{
Rahmat Aulia \\ Balai Diklat Keagamaan Jakarta, Indonesia \\ E-mail:aul_r@yahoo.co.id
}

\begin{abstract}
This study aims to describe an implementation of Kirkpatrick training evaluation model in the subject of ANEKA (Akuntabilitas, Nasionalisme, Etika Publik, Komitmen Mutu dan Anti Korupsi) in Pelatihan Dasar CPNS Calon Hakim MA at Jakarta Education and Religion Training Office involving 119 participants. The evaluation focused in two level namely reaction and learning. To study the first level (reaction) researcher used a questionnaire, whereas at the second level 2 (learning) used test item. The results of the study show that the participants are satisfied in both levels.
\end{abstract}

Keywords: evaluation; Kirkpatrik model; training

\begin{abstract}
Abstrak
Penelitian ini bertujuan untuk mendapatkan gambaran tentang implementasi Evaluasi Model Kirkpatrick pada Pelatihan Dasar CPNS Calon Hakim MA pada Mata Pelatihan Akuntabilitas, Nasionalisme, Etika Publik, Komitmen Mutu dan Anti Korupsi (ANEKA). Metode penelitian ini adalah penelitian deskriptif kualitatif. Penelitian ini mengambil seluruh populasi peserta Pelatihan Dasar CPNS Golongan III Calon Hakim MA, yang dilaksanakan di Balai Diklat Keagamaan Jakarta yang berjumlah 119 orang. Evaluasi level 1 (reaction) dalam penelitian ini dijaring menggunakan angket dan evaluasi level 2 (learning) peserta diperoleh dengan menggunakan hasil evaluasi akademik yang dilakukan diakhir proses pembelajaran. Hasil penelitian menggambarkan reaksi kepuasan peserta pelatihan terhadap program pelatihan memuaskan. Demikian pula halnya hasil evaluasi level 2 model Kirkpatrick pada Pembelajaran Mata Pelatihan ANEKA cukup memuaskan.
\end{abstract}

Kata kunci: Evaluasi program, model kirkpatrik, pelatihan dasar 


\section{PENDAHULUAN}

Peningkatan kualitas sumber daya manusia merupakan suatu yang sangat penting guna meningkatkan akselerasi suatu pembangunan dalam bidang apapun juga, karena kualitas menyangkut peningkatan mutu sumber daya manusia itu sendiri baik kemampuan fisik maupun kemampuan nonfisik. Pendidikan dan pelatihan guna peningkatan sumber daya manusia merupakan hal yang penting dilakukan dalam rangka manajemen sumber daya manusia, sebagai usaha meningkatkan keunggulan bersaing dalam organisasi termasuk organisasi pemerintah. Hal ini terkait erat dengan adanya perubahan dalam lingkungan yang menghendaki organisasi harus melakukan pendidikan dan pelatihan SDM secara lebih proaktif demi mencapai produktifitas kerja yang lebih baik.

$$
\text { Aparatur pemerintah sebagai }
$$
bagian dari sumber daya manusia mempunyai peran penting dalam mengembangkan tatanan pemerintahan. Pergeseran paradigma dari "rule government" menjadi "good governanc" dan dari sentralistik menjadi desentralistik, perlu disikapi dan diimbangi dengan sumber daya aparatur yang memiliki kompetensi yang memadai dan sesuai dengan tuntunan publik, nasional dan tantangan global. Kompetensi menjadi tuntutan dan kewajiban untuk dimilikinya dengan alasan tugas pokok, fungsi, kewenangan dan tanggungjawab yang harus dilaksanakan dalam pelayanan publik, kepemerintahan yang baik, mengimbangi perubahan lingkungan strategis internal dan eksternal, perkembangan ilmu pengetahuan dan teknologi. Kompetensi aparatur merupakan determinan yang penting, karena aparatur pencapain tujuan pendidikan dan pelatihan yang telah ditetapkan. Cronbach dan Suppes serta $A$ Joint Committee on Standars for Evaluation dalam Suparman dan Purwanto (1999) mendefinisikan evaluasi sebagai proses menentukan nilai atau efektivitas suatu kegiatan untuk tujuan pembuatan keputusan. Evaluasi dalam konteks pelatihan dasar CPNS, sebagaimana dikemukakan oleh Junjunan BA (2020) menyatakan bahwa evaluasi latsar bertujuan untuk mengetahui keberhasilan pelaksanaan Latsar CPNS, dimana Pencapaian tujuan penyelenggaraan Latsar CPNS memerlukan kemampuan memberdayakan sumbersumber daya yang tersedia secara efektif dan efisien.

National Study Committee on Evaluation dalam Stark dan Thomas (1994) menyatakan bahwa evaluasi merupakan suatu proses atau kegiatan pemilihan, pengumpulan, analisis dan penyajian informasi yang dapat digunakan sebagai dasar pengambilan keputusan serta penyusunan program selanjutnya. Evaluasi dalam aktivitas pendidikan dan pelatihan dapat berupa evaluasi hasil belajar dan evaluasi program. Evaluasi belajar lebih difokuskan untuk menilai hasil belajar yang dicapai oleh peserta setelah mengikuti pendidikan dan pelatihan. Sedangkan evaluasi program dilakukan untuk menilai efektifitas dan efisiensi program.

Menurut Kirkpatrick (2006) tujuan evaluasi adalah untuk memperoleh informasi yang akurat dan obyektif tentang suatu program yang telah direncanakan dan dilaksanakan. Informasi tersebut dapat berupa proses pelaksaanaan program, dampak/hasil yang dicapai, efisiensi. Hasil evaluasi dapat juga dijadikan tolak ukur apakah program tersebut berhasil atau tidak, dapat dilanjutkan atau dihentikan, serta 
dapat dijadikan pijakan untuk menyusun program lanjutan.

Fink (1995) mendefinisikan program adalah sebuah usaha yang sistematis untuk mencapai sebuah tujuan yang direncanakan sebelumnya. Hal ini senada dengan Rutman dalam Sukardi (2011) yang mengemukakan bahwa program adalah seperangkat kegiatan atau aktifitas yang dirancang untuk mencapai sebuah tujuan. Arikunto (2010) menjelaskan bahwa program merupakan sistem, dimana sistem adalah satu kesatuan dari beberapa bagian atau komponen program yang saling kait-mengkait dan bekerja sama satu dengan yang lainnya untuk mencapai tujuan yang sudah ditetapkan dalam system, sementara itu Widoyoko, E. P. (2017). Menyatakan bahwa program pelatihan merupakan salahsatu strategi pengembangan SDM memerlukan fungsi evaluasi untuk mengetahui efektivitas program yang bersangkutan. Merujuk kepada definisi program di atas dapat disimpulkan bahwa meskipun program diartikan berbeda oleh masing masing ahli, namun program dapat dipahami sebagai serangkaian kegiatan atau aktivitas sistematis yang direncanakan yang dirancang untuk mencapai tujuan tertentu. Dengan kata lain dan sebagai masukan untuk pengambilan keputusan terhadap program yang dievaluasi. Dengan demikian, evaluasi program mengandung tiga unsur penting, yaitu 1) kegiatan sistematis, 2) pengumpulan data dan informasi, dan 3) masukan untuk pengambilan keputusan terhadap program.

Untuk mengevaluasi sebuah program hendaknya memahami bentuk dan makna dari rangkaian kegiatan sebuah evaluasi program. Bentuk evaluasi program sangat bermacam- macam dan beragam sehingga mempengaruhi jenis dan model evaluasi. Berbagai model evaluasi telah banyak dikembangkan dan banyak dipakai sebagai strategi atau pedoman kerja dalam pelaksanaan evaluasi program pendidikan dan pelatihan.

Dalam penelitian ini model evaluasi yang digunakan adalah evaluasi model Kirkpatrick (Kirkpatrick Four Levels Evaluation Models). Penggunaan model evaluasi ini didasarkan atas kesederhanaan, kelengkapan, kejelasan, dan kemudahan dalam mengimplementasikan model tersebut.

Menurut Kirkpatrick (1998) evaluasi terhadap efektivitas program pendidikan dan pelatihan mencakup empat level evaluasi yaitu: level 1 reaction, evaluasi ini dilakukan terhadap reaksi peserta pelatihan/program yang bertujuan untuk mengukur kepuasan peserta (customer satisfaction). Program pelatihan dianggap efektif apabila proses pelatihan dirasa menyenangkan dan memuaskan bagi peserta pelatihan sehingga mereka tertarik, termotivasi untuk belajar dan berlatih.

Menurut Kirkpatrick Mengevaluasi reaksi adalah sama halnya dengan mengukur tingkat kepuasan konsumen. Menurut McLean, S \& Moss G. (2003) evaluasi di level satu biasa disebut dengan "happy face evaluation", pada level ini diukur reaksi dan kepuasan peserta terhadap program pelatihan. Mengukur tingkat kepuasan peserta dalam kegiatan pelatihan merupakan hal yang penting, karena menyangkut motivasi mereka dalam belajar.

Evaluasi dilevel 1 ini tidak mengukur apa yang peserta telah pelajari, namun mengukur minat, motivasi dan tingkat perhatian peserta pelatihan. Kirkpatrick (2006) menambahkan pentingnya mengukur reaksi berdasarkan beberapa 
alasan, yaitu: untuk memberikan masukan yang berharga kepada penyelenggara pelatihan dalam meningkatkan program pelatihan dimasa datang; memberikan saran dan masukan kepada pengajar mengenai tingkat efektifitas mereka dalam mengajar; dapat memberikan informasi kuantitatif kepada para pembuat keputusan terkait dengan pelaksanaan program pelatihan; serta agar dapat memberikan informasi kuantitatif kepada pengajar yang dapat digunakan sebagai dasar untuk membuat standar pengajaran di masa yang akan datang

Level 2 learning, evaluasi level ini difokuskan pada perubahan sikap yang terjadi pada saat kegiatan pelatihan dilakukan sehingga lebih bersifat internal. Peserta pelatihan dikatakan telah belajar apabila pada dirinya telah mengalami perubahan sikap, perbaikan pengetahuan maupun peningkatan keterampilan. Kirkpatrick (1998) mengemukakan "learning can be defined as the extend to which participans change attitudes, improving knowledge, and/or increase skill as a result of attending the program".

Evaluasi level 3 behavior (evaluasi tingkah laku), evaluasi level ini difokuskan pada perubahan tingkah laku setelah mengikuti pelatihan akan diimplementasikan setelah peserta mengikuti pendidikan dan pelatihan, sehingga penilaian tingkah laku ini lebih bersifat eksternal. Level evaluasi yang terakhir menurut Kirkpatrick adalah level 4, yaitu result (hasil akhir) yang terjadi karena peserta telah mengikuti suatu program. Dalam kegiatan pendidikan dan pelatihan dan ataupun pembelajaran model evaluasi ini mengarah pada hasil akhir yang diperoleh peserta. Penelitian ini akan mengimplementasikan evaluasi model Kirkpatric pada pembelajaran mata diklat ANEKA bagi peserta LATSAR
CPNS/CAKIM MA yang dilaksanakan di Balai Diklat Keagamaan Jakarta hanya pada level 1 dan level 2.

\section{METODE}

Penelitian ini dilakukan untuk mendapatkan gambaran tentang implementasi Evaluasi Model Kirkpatrick pada pembelajaran mata diklat Akuntabilitas, Nasionalisme, Etika Publik, Komitmen Mutu, dan Anti Korupsi (ANEKA). Jenis penelitian ini adalah penelitian deskriptif kualitatif. Implementasi evaluasi model Kirkpatric yang dievaluasi pada penelitian ini hanya level 1 dan level 2 data tentang evaluasi model Kirkpatrick dijaring dengan menggunakan instrumen. Level 1 mengenai reaksi peserta terhadap peoses pembelajaran yang dilakukan. Data dijaring dengan menggunakan angket, sedangkan level 2 data hasil belajar peserta dijaring berdasarkan hasil evaluasi akademik yang dilakukan pada akhir proses pembelajaran. Subjek dalam penelitian ini adalah peserta LATSAR CPNS Golongan III Calon Hakim MA Angkatan LXVIII, LXIX, dan LXX yang berjumlah 119 orang.

\section{HASIL DAN PEMBAHASAN \\ Evaluasi Level 1 - Reaksi (Reaction)}

Kepuasan peserta terhadap proses pembelajaran yang dilakukan dikaji dari beberapa aspek, yaitu materi yang diberikan, fasilitas yang tersedia, strategi atau cara penyampaian materi oleh fasilitator (nara sumber, widyaiswara) dan media pembelajaran yang tersedia. Gambaran tingkat kepuasan peserta terhadap proses pembelajaran pada aspek relevansi materi adalah 76 orang atau $63,9 \%$ peserta menyatakan sangat memuaskan, 30 orang atau 25,2\% peserta 
menyatakan memuaskan, 9 orang atau 7,5\% menyatakan kurang memuaskan dan 4 orang atau 3,4\% menyatakan tidak memuaskan. Gambaran tingkat kepuasan peserta pada aspek ini terlihat pada grafik berikut:

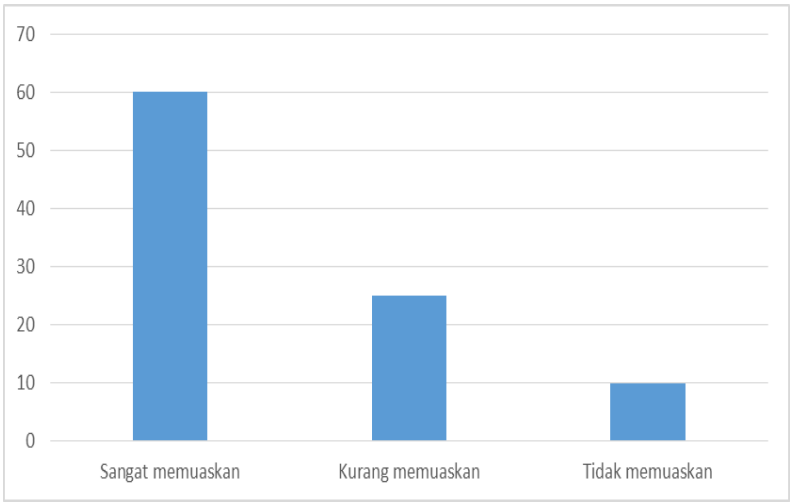

Gambar 1. Kepuasan peserta

Dari hasil yang diperoleh seperti pada Gambar 1, maka dapat dikatakan bahwa peserta yang mengikuti pelatihan pada agenda Nilai-Nilai Dasar PNS yang terdiri

dari mata pelatihan Akuntabilitas, Nasionalisme, Etika Publik, Komitmen Mutu dan Anti Korupsi (ANEKA) memberikan reaksi yang positif terhadap proses pembelajaran dari aspek relevansi materi yang diberikan yang memuaskan.

Evaluasi ini menjadi acuan untuk melakukan perbaikan ataupun peningkatan dan pengembangan materi atau modul yang disediakan oleh pihak-pihak yang berkepentingan guna mendukung kelancaran proses pembelajaran yang pada akhirnya akan menghasilkan kompetensi yang diharapkan.

Kepuasan peserta terhadap proes pembelajaran pada aspek ketersediaan fasilitas pembelajaran adalah 65 orang atau 54,6\% peserta menyatakan sangat memuaskan terhadap fasilitas yang tersedia pada proses pembelajaran, 30 orang atau 25,2\% peserta menyatakan memuaskan, 14 orang atau 11,8\% menyatakan kurang memuaskan dan 10 orang atau $8,4 \%$ peserta menyatakan fasilitas yang tersedia pada proses pembelajaran tidak memuaskan.
Gambaran tingkat kepuasan peserta pada aspek ini terlihat pada grafik berikut:

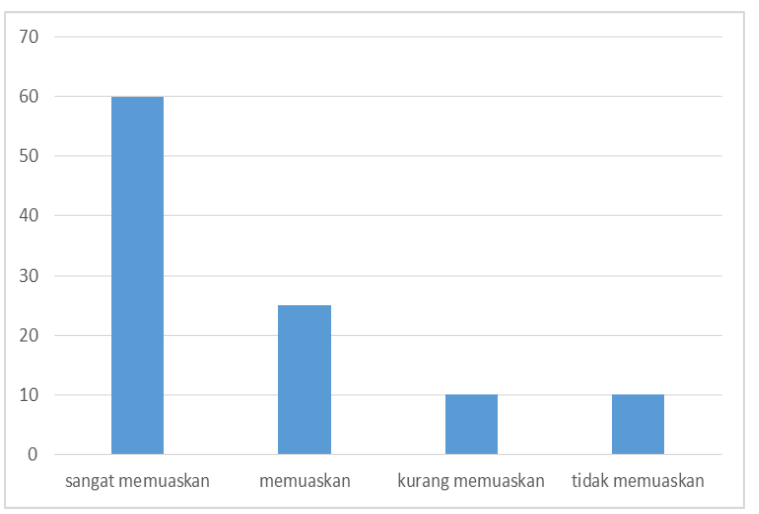

Gambar 2. Reaksi Peserta Terhadap Proses Pembelajaran pada Aspek Fasilitas yang Tersedia.

Dari hasil yang diperoleh seperti pada Gambar 2, dapat disimpulkan bahwa peserta yang mengikuti pelatihan pada agenda Nilai- Nilai Dasar PNS yang terdiri dari mata pelatihan Akuntabilitas, Nasionalisme, Etika Publik, Komitmen Mutu dan Anti Korupsi (ANEKA) memberikan reaksi yang positif terhadap proses pembelajaran dari aspek ketersedian fasilitas pembelajaran meskipun belum tersedian lengkap.

Hal ini mengindikasikan perlunya fasilitas pembelajaran yang mendukung suatu progran pendidikan dan pelatihan, karena ketersedian fasilitas yang lengkap akan menambah perhatian, semangat serta peningkatan dalam sebuah kegiatan pembelajaran. Ketersedian fasilitas dalam proses pembelajaran adalah sesuatu yang mutlak diperlukan guna mencapai kompetensi yang diharapkan.

Adapun presentase kepuasan peserta terhadap proses pembelajaran pada aspek strategi atau cara penyampaian materi oleh fasilitator adalah untuk 63 orang atau $53 \%$ peserta menyatakan sangat memuaskan, 20 orang atau 16,8\% peserta menyatakan memuaskan, peserta yang menyatakan strategi atau cara penyampaian materi yang dilakukan fasilitator krang memuaskan adalah 20 
orang atau 16,8. Sisanya yaitu 16 orang atau $13,4 \%$ menyatakan strategi atau cara penyampaian materi oleh fasilitator tidak memuaskan. Gambar tingkat kepuasan proses pembelajaran pada aspek ini adalah sebagai berikut:

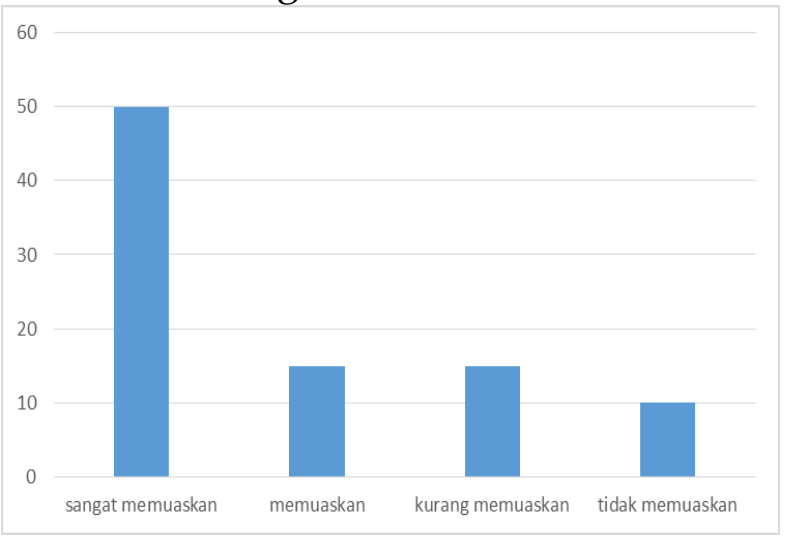

Gambar 3. Reaksi Peserta Terhadap Proses Pembelajaran pada Aspek Strategi/Cara Penyampaian oleh Fasilitator.

Berdasarkan hasil yang terlihat pada gambar 3, tingkat kepuasan peserta pada proses pembelajan pasa aspek strategi atau cara yang digunakan fasilitator untuk menyampaikan materi juga mendapat reaksi positif, namun demikian fasilitator perlu terus mengembangkan kompetensi dan mengupdate pengetahuannya dalam penyempurnaan dan peningkatan kepuasan peserta dalam proses pembelajaran di masa yang akan datang. Hal ini dikarenakan fasilitator adalah ujung tombak dalam pelaksanaan sebuah program pendidikan dan pelatihan. Hasil ini juga menjadi acuan untuk melakukan perbaikan ataupun peningkatan kualitas proses belajar mengajar oleh nara sumber atau widyaiswara.

Tingkat kepuasan peserta pada proses pembelajaran pada aspek media pembelajaran adalah 63 orang atau 53\% menyatakan bahwa media pembelajaran sangat memuaskan, 25 orang atau 21\% menyatakan memuaskan sebagaimana terlihat pada gambar berikut :

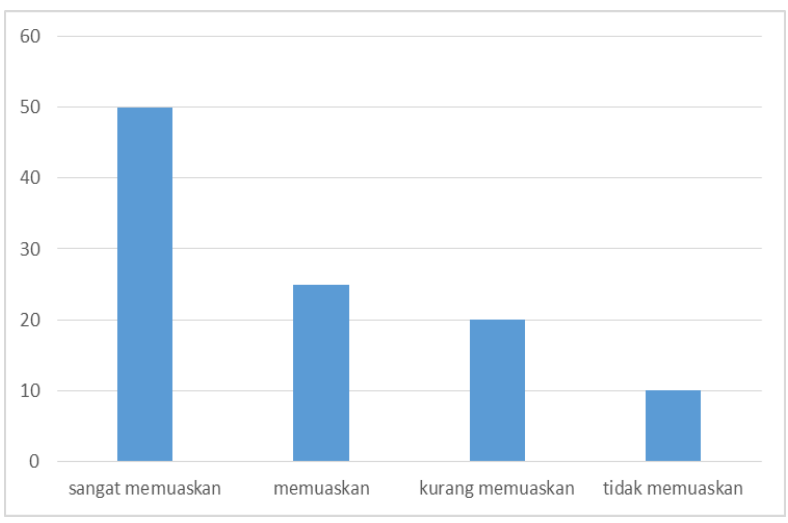

Gambar 4. Reaksi Peserta Terhadap Proses Pembelajaran pada Aspek Media.

Dari hasil yang diperoleh seperti pada Gambar 4, maka dapat dikatakan bahwa peserta yang mengikuti pelatihan pada agenda Nilai-Nilai Dasar PNS yang terdiri dari mata pelatihan Akuntabilitas, Nasionalisme, Etika Publik, Komitmen Mutu dan Anti Korupsi (ANEKA) memberikan reaksi yang positif terhadap proses pembelajaran yang dilakukan dilihat dari aspek ketersedian media pembelajar.

Sebagai salah satu unsur yang mendukung kelancaran proses pembelajaran, ketersediaan media tidak bisa diabaikan, hal ini senada dengan apa yang dikemukakan oleh Oktaviani, R. T. (2019). Media Pembelajaran dapat mengatasiketerbatasan pengalaman yang dimiliki oleh para peserta didik. Oleh karena itu segenap pemangku yang berkepentingan harus selalu memperhatikan sarana prasarana pembelajaran dalam hal ini media pembelajaran bila menginginkan pembelajaran yang sesuai dengan apa yang diharapkan.

\section{Evaluasi Level 2 - Pembelajaran (Learning)}

Kirkpatrick (2006) menyatakan evaluasi di level-2 berhubungan dengan pengukuran peningkatan kompetensi peserta, baik dari segi 
pengetahuan, keterampilan, dan sikap sesuai dengan tujuan diadakannya pelatihan. Pembelajaran didefinisikan sebagai prinsip, fakta-fakta, dan teknik yang dimengerti dan diserap oleh peserta. Kennedy, E., P., Chyung, Y., S., Winiecki, J., D., \& Brinkerhoff, O., R. (2013) menyatakan bahwa kegunaan evaluasi bertujuan mengukur seberapa baik peserta didik dalam mempelajari pengetahuan atau keterampilan yang disampaikan dalam learning lebih mengarah pada penilaian hasil (output) belajar. Pembelajaran Mata Pelatihan ANEKA dilakukan dengan harapan untuk mengembangkan dan memberikan bekal kepada peserta dalam melakukan tugas dan fungsinya sebagai pelayan publik yang profesional. Evaluasi pembelajaran peserta dilakukan secara individu, Evaluasi ini dilakukan untuk mengetahui penguasaan peserta terhadap konsep mata pelatihan, penalaran, komunikasi, sikap dan keterampilan serta pemecahan masalah. Bentuk soal dalam evaluasi ini terdiri dari dua tipe yaitu tipe A dan tipe B. Tipe A terdiri dari 80 pilihan ganda, dan tipe B terdiri dari 5 soal analisis kasus. Skor tertinggi yang adalah 20 dan skor terendah adalah 0 .

Adapun skor peserta pelatihan angkatan LXVIII adalah sebagai berikut :

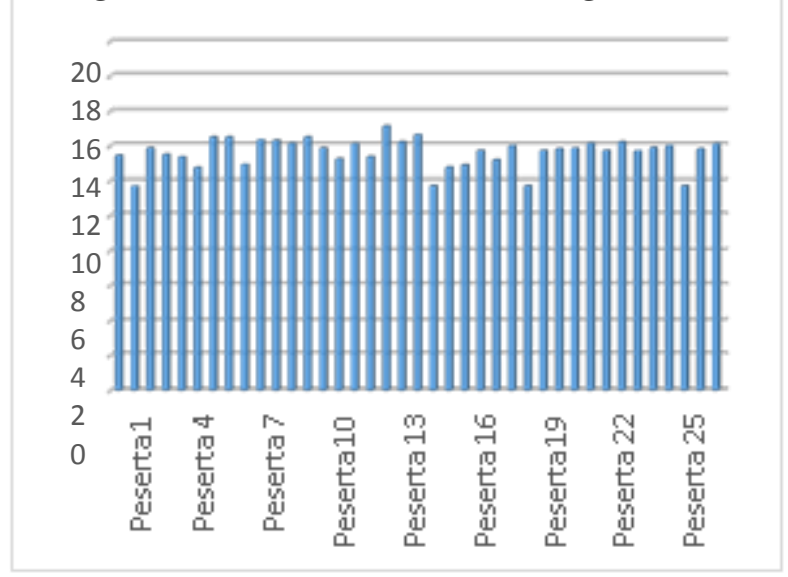

Gambar 5. Hasil Evaluasi Pembelajaran Peserta Angkatan XLVIII Melalui Evaluasi Akademik.
Dari hasil yang diperoleh seperti pada Gambar 5. Diperoleh hasil bahwa skor tertinggi peserta adalah 15,12, skor terendah 11, 67. Rata-rata skor yang diperoleh peserta adalah 13,6. Hal ini menunjukkah bahwa kemampuan peserta angkatan LXVIII pada mata pelatihan ANEKA memuaskan.

Skor yang diperoleh peserta angkatan LXIX adalah sebagai berikut:

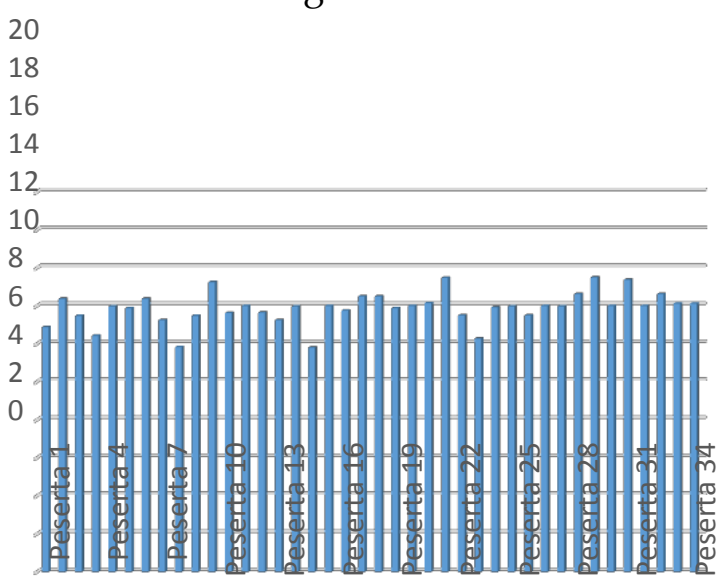

Gambar 7. Hasil Evaluasi Pembelajaran Peserta Angkatan XLXX Melalui Evaluasi Akademik.

Dari hasil yang diperoleh seperti pada Gambar 7. Diperoleh hasil bahwa skor tertinggi peserta angkatan XLXX adalah 15,50 , skor terendah 11,80. Rata-rata skor peserta adalah 13,88. Hal ini menunjukkan bahwa kemampuan peserta angkatan LXX pada mata pelatihan ANEKA memuaskan. Level kedua yang diukur adalah aspek pembelajaran peserta yang berkaitan dengan pengetahuan. Pada level kedua peserta yang mengikuti mata pelatihan ANEKA dinilai kemampuan dan pengetahaunnya melalui evaluasi akademik. Hal ini dilakukan untuk

mengetahui semua potensi yang dimiliki oleh peserta. Level kedua pada evaluasi model Kirkpatrick menjabarkan aspek-aspek penilaian secara menyeluruh dan kriteria penilaian yang jelas. Kriteria pemahaman konsep terdiri dari menunjukkan pemahaman terhadap konsep Mata Pelatihan ANEK. Peserta diukur pada tingkat penguasaan konsep ANEKA. Penguasaan konsep sangat bermanfaat untuk melakukan kegiatan selanjutnya sera membekali peserta ketika 
ASN.

melakukan tugas dan fungsinya selaku

\section{KESIMPULAN}

Implementasi Evaluasi Model

Kirkpatrick pada Program pelatihan Dasar CPNS di mata pelatihan ANEKA efektif untuk membekali, menambah kemampuan dan kompetensi peserta ketika menjalankan tugasnya sebagai pelayan publik, mampu membuat peserta untuk mengaplikasikan konsep-konsep pada mata pelatihan ANEKA dalam menjalankan peran dan fungsinya sebagai ASN. Dalam proses pembelajaran dibutuhkan fasilitator (nara sumber dan widyaiswara) yang mempunyai kemampuan mengajar dengan baik, dan juga mampu melakukan evaluasi yang efektif. Model Kirkpatrick merupakan alternatif bagi fasilitator (nara sumber dan widyaiswara) untuk mendapatkan gambaran tentang kemampuan peserta pada agenda Nilai-Nilai Dasar PNS yang ada dalam mata pelatihan ANEKA.

Evaluasi proses pembelajaran dilakukan secara menyeluruh, baik dari proses pembelajaran maupun hasil belajar peserta.

Penilaian proses pembelajaran dilakukan untuk mengetahui kemampuan mahasiswa terhadap indikator-indikator dari suatu mata pelatihan. Hasil penelitian ini menunjukkan bahwa dengan menggunakan evaluasi model Kirkpatrick pada proses pembelajaran mata pelatihan ANEKA pada Pelatihan Dasar CPNS, aktifitas belajar pesrta cukup efektif dan mampu mengeksplorasi kemampuan peserta. 
Wawasan

Jurnal Kediklatan Balai Diklat Keagamaan Jakarta PISSN 2548-9232; ${ }_{\mathrm{E}}$ ISSN ...

Volume 1 Nomor 1 Tahun 2020

\section{DAFTAR PUSTAKA}

Arlene Fink, (1995). Evaluation for Education Evaluation and Psychology. London: Sage Publication

Eko Putro Widoyoko, (2010). Evaluasi Program Pembelajaran,Yogyakarta: Pustaka Pelajar

Widoyoko, E. P. (2017). Evaluasi Program Pelatihan. Yogyakarta: Pustaka Pelajar.

Garfield, J. B. (1994) Beyond Testing and Grading Using Assessment to Improve Student Learning.

Griffin, P., dan Nix, P. (1991). Educational Assessment and Reporting. Sydney: Harcout Brace Javanovich Publisher.

Junjunan, B. A. (2020). Evaluasi Pembelajaran Nilai-Nilai Aneka dan Pengaruhnya Terhadap Perilaku Alumni Latsar CPNS. Jurnal Ilmiah Universitas Batanghari Jambi, 20(3), 946-951.

Kirkpatrick, D., L., \& Kirkpatrick J., D. (2006). Evaluating Training Programs The Four Levels. San Fransisco: Berret-Kohler Publisher, Inc

Kennedy, E., P., Chyung, Y., S., Winiecki, J., D., \& Brinkerhoff, O., R., (2013). Training Profesionals Usage and Understanding of Kirkpatrick's Evaluation. International Journal of Training and Development. ISSN 1360-3736.

Oktaviani, R. T. (2019). Pemanfaatan Video sebagai Media Pembelajaran dalam Pendidikan dan Pelatihan (Diklat). MADIKA: Media Informasi dan Komunikasi Diklat Kepustakawanan, 5(1), 91-94.

Peraturan Kepala LAN RI Nomor 21 tahun (2016) tentang Pedoman Penyelenggaraan

Pelatihan Dasar Calon PNS.

Purwanto \& Suparman, (1999). Evaluasi Program Diklat. Jakarta: Sekolah Tinggi Ilmu Administrasi Lembaga Administrasi Negara.

Suharsimi Arikunto, (2010). Evaluasi Program Pendidikan Jakarta: Bumi Aksara.

Sukardi, (2011). Evaluasi Pendidikan Prinsip E Operasionalnya. Jakarta: Bumi Aksara.

Stark, J. S., dan Thomas, A. (1994). Assessment and Program Evaluation. Needham Heights: Simon \& Schuster Custom Publishing. 


\section{Wawasan}

Jurnal Kediklatan Balai Diklat Keagamaan Jakarta PISSN 2548-9232; ${ }_{\text {ISSN ... }}$

Volume 1 Nomor 1 Tahun 2020

Undang-Undang RI Nomor 5 tahun 2014 tentang Aparatur Sipil Negara. 